\title{
PENGARUH KUALITAS PELAYANAN TERHADAP PENGRUH KEPUASAN KONSUMENN PENGGUNA TRASNPORTASI UMUM TRANSJAKARTA (STUDI KASUS PADA MAHASISWA ADMINISTRASI NIAGA POLITEKNIK NEGERI JAKARTA)
}

\author{
Ayu Wahyuningsih ${ }^{1}$ dan Endah Wartiningsih ${ }^{2}$ \\ ${ }^{1,2}$ Administrasi Bisnis Terapan, Politeknik Negeri Jakarta \\ Email : ${ }^{1}$ ayuwahyuu@gmail.com ${ }^{2}$ endah.wartiningsih@bisnis.pnj.ac.id
}

\begin{abstract}
This study aims to observe the quality of service towards the satisfaction of Transjakarta passengers; specifically to Business Administration Student, State Polytechnic of Jakarta. This study used survey research method as part of quantitative approach. In collecting data, this study applied both primary and secondary as supporting resources. This study involved 214 population; 139 respondents were obtained through Slovin formula method. The results show that; (a) this research is qualified for a normal distribution, which is 0,200 $>0,05$, and the direction of this research is positive, where $Y=$ $13,465+0,866 X$. In addition, there is an intense correlation between variable, in amount of 0.887 . (b) Value of effect from service quality variable has a substantial contribution to customer satisfaction, at 78,6\%, and 21,4\% are influenced by another factor. (c) Based on the response of service quality, reliability indicator created the strong relation compared to responsiveness as the lowest/weakest indicator. Regarding respondents' responses to customer satisfaction; the biggest indicator in creating the strong relation is emphaty whilst the reliability is positioned at the lowest/weakest indicator.
\end{abstract}

Keywords: Service Quality, Customer Satisfaction, Transjakarta

\section{Abstrak}

Penelitian ini bertujuan untuk mengetahui pengaruh kualitas pelayanan terhadap kepuasan konsumen pengguna transportasi umum Transjakarta pada mahasiswa Administrasi Niaga Politeknik Negeri Jakarta. Metode penelitian yang digunakan dalam penelitian ini adalah penelitian survei yang merupakan salah satu bagian dari pendekatan penelitian kuantitatif. Pengumpulan data menggunakan data primer dan sekunder.. Populasi dalam penelitian ini sebanyak 214 orang dan sampel yang didapatkan dengan menggunakan metode rumus Slovin sebanyak 139 responden. Hasil penelitian ini menunjukkan bahwa: (a) penelitian ini memenuhi syarat distribusi normal, dimana 0,707 $>0,05$. Dan hasil penelitian diketahui bahwa arah penelitian ini positif yaitu $Y=15,667+0,743 X$. Selain itu diketahui bahwa terdapat hubungan atau korelasi yang sangat kuat antar variabel yaitu sebesar 0,791, (b) nilai pengaruh yang dihasilkan variabel kualitas pelayanan memiliki kontribusi yang cukup besar terhadap kepuasan konsumen pengguna transportasi umum Transjakarta yaitu sebesar 62,6\%. Sedangkan sisanya sebesar 37,4\% dipengaruhi oleh faktor lain diluar dari penelitian ini. (c) berdasarkan tanggapan responden terhadap kualitas pelayanan, diketahui indikator bukti fisik menciptakan hubungan yang paling kuat dan indikator terendah adalah daya tanggap. Untuk tanggapan responden terhadap kepuasan konsumen indikator yang paling besar menciptakan hubungan paling kuat adalah kepuasan terhadap empati dan indikator terendah adalah kepuasan terhadap bukti fisik.

Kata Kunci: Kualitas Pelayanan, Kepuasan Konsumen, Transjakarta

\section{PENDAHULUAN}

Dewasa ini, jasa merupakan salah satu kebutuhan yang tidak dapat dihindari oleh manusia. Sejalan dengan banyaknya aktivitas manusia, saat ini banyak ditemukan penyedia jasa dengan bermacam jenis jasa yang bervariasi. Tujuan utama perusahaan penyedia jasa adalah untuk 
memenuhi kebutuhan dan keinginan masyarakat sehingga masyarakat sebagai konsumen merasa puas.

Semakin tinggi tingkat mobilitas penduduk suatu negara, semakin tinggi tingkat kebutuhan akan jasa. Pengguna jasa semakin meningkat setiap tahunnya, salah satu bidang jasa yang meningkat jumlah penggunanya yaitu jasa transportasi. Jakarta merupakan kota yang identik dengan masalah kemacetan. Pada dasarnya kemacetan disebabkan oleh banyaknya masyarakat yang menggunakan kendaraan pribadi.

Berdasarkan meningkatnya kebutuhan masyarakat perkotaan akan transportasi umum, pemerintah DKI Jakarta menyediakan Transjakarta sebagai salah satu pilihan alternatif transportasi umum yang nyaman, cepat dengan harga yang terjangkau. Transjakarta telah banyak diminati oleh masyarakat DKI Jakarta. Hal ini dibuktikan dengan peningkatan jumlah pengguna Transjakarta setiap tahunnya yaitu pada tahun 2015 jumlah pengguna Transjakarta mencapai 102,8 juta orang, lalu pada tahun 2016 bertambah 20 persen menjadi 123,7 juta orang dan pada tahun 2017 meningkat sebanyak 50 persen mencapai 144,86 juta orang. Dapat dilihat pada gambar 1.1 di bawah ini, yaitu:

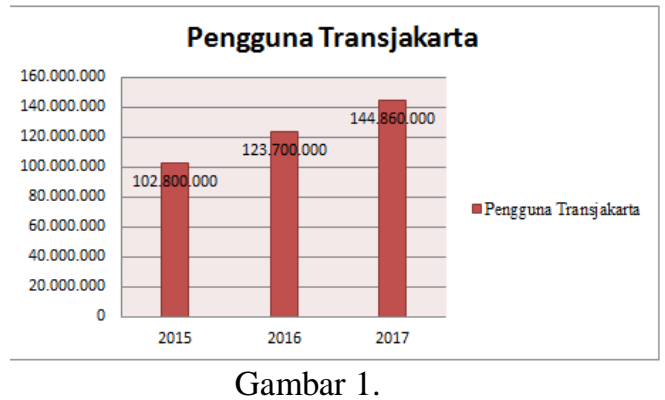

Jumlah Penumpang Transjakarta tahun 20152017 (Sumber: www.republika.co.id, 2018)

Transjakarta merupakan sarana transportasi milik PT Transportasi Jakarta. Transjakarta merupakan salah satu bentuk sarana transportasi umum yang disediakan oleh pemerintah DKI Jakarta untuk menunjang kebutuhan aktifitas masyarakat sehari-hari. Sarana pendukung trasnportasi umum ini juga dilengkapi dengan sejumlah fasilitas seperti jalur khusus (busway) yang membuat penumpang dapat lebih nyaman untuk terhindar dari kemacetan, juga tempat halte yang tertutup dari hujan, bus yang digunakan memiliki AC dan juga cara pembayaran yang fleksibel dengan $e$ money maupun pembayaran konvensional dihalte-halte tertentu. Saat ini Transjakarta telah melayani rute perjalanan sebanyak 260 halte, mencakup rute ke daerah-daerah penyangga Jakarta seperti Bekasi, Tangerang, Depok, dan Tanjung Priok.

Dibalik seluruh pelayanan yang telah disediakan tersebut, kualitas pelayanan yang diberikan pihak Transjakarta belum dapat memberikan kepuasan kepada konsumen secara maksimal. Masih banyak konsumen yang merasa bahwa pelayanan yang diberikan belum memenuhi keinginan dan harapan konsumen. Memberikan pelayanan yang dapat memuaskan konsumen untuk produk atau jasa yang berkualitas terbilang sulit, terlebih saat ini banyak perusahaan penyedia jasa dalam bidang yang sama berlomba-lomba untuk meningkatkan kualitas demi menarik konsumen. Pada dasarnya, produk berkualitas adalah produk yang memenuhi harapan konsumen. Kualitas didefinisikan sebagai tingkat keunggulan, sehingga kualitas merupakan ukuran yang relatif. Kualitas layanan harus dimulai dari kebutuhan pelanggan dan berakhir dengan kepuasan pelanggan serta persepsi positif terhadap kualitas layanan.

Kepuasan konsumen dapat dicapai dengan memberikan kualitas yang baik. Kepuasan yang tinggi dari konsumen akan mendorong loyalitas yang tinggi bagi perusahaan. Perusahaan jasa perlu mengetahui bahwa setiap konsumen memiliki pandangan atau persepsi yang berbeda-beda mengenai jasa atau service yang diberikan.

Berdasarkan latar belakang yang telah dijelaskan, penulis akan melakukan penelitian dengan judul "Pengaruh Kualitas Pelayanan Terhadap Kepuasan Konsumen Pengguna Transportasi Umum Transjakarta (Studi Kasus pada Mahasiswa 
Administrasi Niaga Politeknik Negeri Jakarta)”.

\section{Rumusan Masalah}

Rumusan masalah pada penelitian ini adalah adakah pengaruh kualitas pelayanan Transjakarta terhadap kepuasan konsumen pada Mahasiswa/i Administrasi Niaga Politeknik Negeri Jakarta?

\section{Tinjauan Pustaka \\ Kualitas Pelayanan}

Menurut Wijaya (2011:11), pengertian kualitas, yaitu sesuatu yang diputuskan oleh pelanggan atau konsumen. Artinya, kualitas didasarkan pada pengalaman aktual pelanggan atau konsumen terhadap produk atau jasa yang diukur berdasarkan persyaratan-persyaratan tersebut. Jasa adalah setiap tindakan atau kegiatan yang dapat ditawarkan oleh satu pihak kepada pihak lain, yang pada dasarnya tidak berwujud dan tidak mengakibatkan kepemilikan apapun. Produksinya dapat dikaitkan atau tidak dikatikan dengan produk fisik (Kotler \& Keller, 2009:36).

Lupioyadi (2016:231), mendefinisikan kualitas pelayanan merupakan faktor yang menentukan tingkat keberhasilan dan kualitas perusahaan dimana kemampuan perusahaan dalam memberikan pelayanan yang berkualitas kepada konsumen dan sebagai strategi untuk mempertahankan diri dan mencapai kesuksesan dalam menghadapi persaingan jasa atau produk melainkan saat sebelum dan sesudah pelayanan.

Berdasarkan beberapa pengertian tersebut dapat disimpulkan bahwa kualitas pelayanan didefinisikan sebagai seberapa jauh perbedaan antara kenyataan dan harapan pelanggan atas layanan yang mereka terima (Parasuraman dkk., 1998 dalam Lupiyoadi, 2016:234).

Terdapat lima dimensi SERVQUAL menurut Parasuraman dkk. (1998) dalam Lupiyoadi (2016:235) yaitu:

a. Berwujud (tangible)

Yaitu kemampuan suatu perusahaan dalam menunjukan eksistensinya kepada pihak eksternal. Penampilan dan kemampuan sarana dan prasarana fisik perusahaan yang dapat diandalkan keadaan lingkungan sekitarnya merupakn bukti nyata dari pelayanan yang diberikan oleh pemberi jasa. Hal ini meliputi fasilitas fisik (contoh: gedung, gudang, dan lain-lain), perlengkapan dan peralatan yang digunakan (teknologi), serta penampilan pegawainnya.

b. Kehandalan (reliability)

Yaitu kemampuan perusahaan untuk memberikan pelayanan sesuai dengan yang dijanjikan secara akurat dan terpercaya. Kinerja harus sesuai dengan harapan pelanggan yang berarti ketepatan waktu, pelayanan yang sama untuk semua pelanggan tanpa kesalahan, sikap yang simpatik, dan dengan akurasi yang tinggi.

c. Ketanggapan (responsivness)

Yaitu suatu kebijakan untuk membantu dan memberikan pelayanan yang cepat (responsif) dan tepat kepada pelanggan, dengan penyampaian informasi yang jelas. Membiarkan pelanggan menunggu menciptakan persepsi yang negatif dalam kualitas pelayanan.

d. Jaminan dan kepastian (assurance) Yaitu pengetahuan, kesopansantunan, dan kemampuan para pegawai perusahaan untuk menumbuhkanrasa percara para pelanggan kepada perusahaan. Hal ini meliputi beberapa komponen antara lain komunikasi, kredibilitas, keamanan, kompetensi, dan sopan santun.

e. Empati (empathy)

Yaitu memberikan perhatian yang tulus dan bersifat individual atau pribadi yang diberikan kepada para pelanggan dengan berupaya memahami keinginan mereka. Hal ini mengharapkan bahwa suatu perusahaan memiliki pengertian dan pengetahuan tentang pelanggan, memahami kebutuhan pelanggan secara spesifik, serta memiliki waktu pengoprasian yang nyaman bagi pelanggan. 


\section{Kepuasan Konsumen}

Menurut Kotler dalam Wijaya (2011:2), kepuasan konsumen merupakan fungsi dari pandangan terhadapa kinerja produk atau jasa dan harapan konsumen. Jika kinerja berada di bawah harapan maka konsumen tidak puas. Jika kinerja memenuhi harapan maka konsumen puas. Jika kinerja melebihi harapan, konsumen sangat puas atau senang.

Kepuasan konsumen diukur dengan instrumen yang sama dengan dimensi kualitas pelayanan, dimana responden ditanyakan apa yang dirasakan (performance) dan apa yang diharapkannya (expectation).

Menurut (Kotler \& Keller, 2008) pelanggan membentuk ekspektasi jasa dari banyak sumber, seperti pengalaman masa lalu, berita dari mulut ke mulut, dan iklan. Secara umum, pelanggan membandingkan jasa anggapan (perceived service) dan jasa yang diharapkan (expected service). Jika jasa anggapan berada di bawah jasa yang diharapkan, pelanggan kecewa.

Adapun dimensi kepuasan konsumen menurut Kotler (2001) yaitu:

a. Bukti Fisik (Tangibles)

Kemampuan suatu perusahaan dalam menunjukkan eksistensinya kepada pihak luar. Penampilan dan kemampuan sarana dan prasarana fisik perusahaan dan keadaan lingkungan sekitarnya adalah bukti nyata dari pelayanan yang diberikan perusahaan pemberi jasa. Bukti fisik tersebut meliputi penampilan fisik, peralatan, karyawan, mekanik, media komunikasi dan teknologi yang dipergunakan dalam memberikan pelayanan.

b. Kehandalan (Reliability)

Kemampuan untuk melaksanakan jasa yang dijanjikan secara terpercaya dan akurat.

c. Daya Tanggap (Responsiveness)

Kemampuan untuk membantu pelanggan dan memberikan jasa dengan cepat.

\section{d. Jaminan (Assurance)}

Pengetahuan terhadap produk secara tepat, kesopan-santunan karyawan dalam memberikan pelayanan, keterampilan dalam memberikan informasi, kemampuan dalam memberi pelayanan dan kemampuan dalam menanamkan kepercayaan dan keyakinan konsumen terhadap perusahaan.

e. Empati (Empathy)

Syarat untuk peduli, memberikan perhatian pribadi bagi konsumen.

Menurut Irawan (2009:37-39), ada lima faktor yang mempengaruhi kepuasan konsumen, yaitu:

a. Kualitas Produk

Konsumen akan puas apabila setelah membeli dan menggunakan produk tersebut ternyata kualitas produknya baik.

b. Kualitas Pelayanan

Kualitas pelayanan sangat bergantung pada tiga hal, yaitu sistem, teknologi, dan manusia. Kepuasan terhadap kualitas pelayanan biasanya sulit ditiru.

c. Harga

Untuk pelanggan yang sensitif biasanya harga murah adalah sumber kepuasan yang penting karena konsumen akan mendapatkan value for money yang tinggi.

d. Emosi

Konsumen akan merasa puas karena adanya emotional value yang diberikan oleh produk atau jasa tersebut.

e. Biaya

Hal ini berkaitan dengan biaya dan kemudan untuk mendapatkan produk atau jasa tersebut. pelanggan akan merasa puas apabila relatif mudah, nyaman, dan efisien dalam mendapatkan produk atau jasa tersebut.

\section{METODE PENELITIAN}

Metode penelitian yang digunakan dalam penelitian ini adalah rumusan masalah asosiatif - hubungan kausal yang merupakan salah satu bagian dari 
pendekatan penelitian kuantitatif. Penelitian ini termasuk penelitian kuantitatif karena hasil dari penelitian ini akan dihubungkan untuk menunjukkan adanya pengaruh antar variabel dengan analisis data statistik.

\section{Populasi dan Sampel}

Populasi yang digunakan dalam penelitian ini adalah mahasiswa/i Administrasi Niaga Politeknik Negeri Jakarta yang pernah menggunakan Transjakarta dengan jumlah populasi sebanyak 214 orang. Penelitian ini mengambil sampel dengan metode sampling purposive. Berdasarkan kriteria pemilihan responden, maka sampel pada penelitian ini berjumlah 139 orang.

\section{Teknik Pengumpulan Data}

Teknik yang digunakan dalam pengumpulan data pada penelitian ini adalah data primer dan data sekunder.

\section{Teknik Pengolahan Data}

Metode pengolahan data dalam penelitian ini menggunakan software SPSS (Stastitical Package for Social Science) versi 20. Kegiatan pengolahan data ini meliputi beberapa tahapan, yaitu:

a. Editing (Pengeditan)

Proses ini adalah proses pengecekan dan pengoreksian data yang telah dikumpulkan dari hasil survei dilapangan agar data yang akan dianalisis menjadi akurat dan lengkap karena kemungkinan data yang masuk atau data yang terkumpul meragukan dan tidak logis.

b. Coding (Pemberian Kode)

Proses coding adalah proses pemberian atau pembuatan kode-kode pada tiaptiap data yang tergolong dalam kategori yang sama. Kode adalah isyarat yang dibuat dalam bentuk angka-angka atau huruf-huruf yang memberikan petunjuk, atau identitas pada suatu informasi atau data yang akan dianalisis. c. Tabulasi

Tabulasi adalah proses membuat tabeltabel yang berisikan data yang telah diberikan kode sesuai dengan kode yang dibutuhkan. Dalam proses tabulasi ini juga terdapat tahap scoring. Scoring adalah suatu kegiatan berupa pemberian skor pada jawaban kuesioner. Skala yang digunakan untuk kuesioner penelitian ini yaitu skala likert.

\section{Teknik Analisis Data}

Teknik analisis data yang digunakan dalam penelitian ini antara lain uji instrumen, uji asumsi klasik yang meliputi uji normalitas, uji linieritas dan uji hipotesis yang meliputi analisis regresi linier sederhana, analisis korelasi sederhana, uji statistik t, dan uji koefisien determinasi $\left(\mathrm{R}^{2}\right)$.

\section{HASIL DAN PEMBAHASAN}

Hasil penelitian yang dilakukan melalui tahap pengumpulan, pengolahan dan analisis data adalah sebagai berikut:

a. Uji instrumen

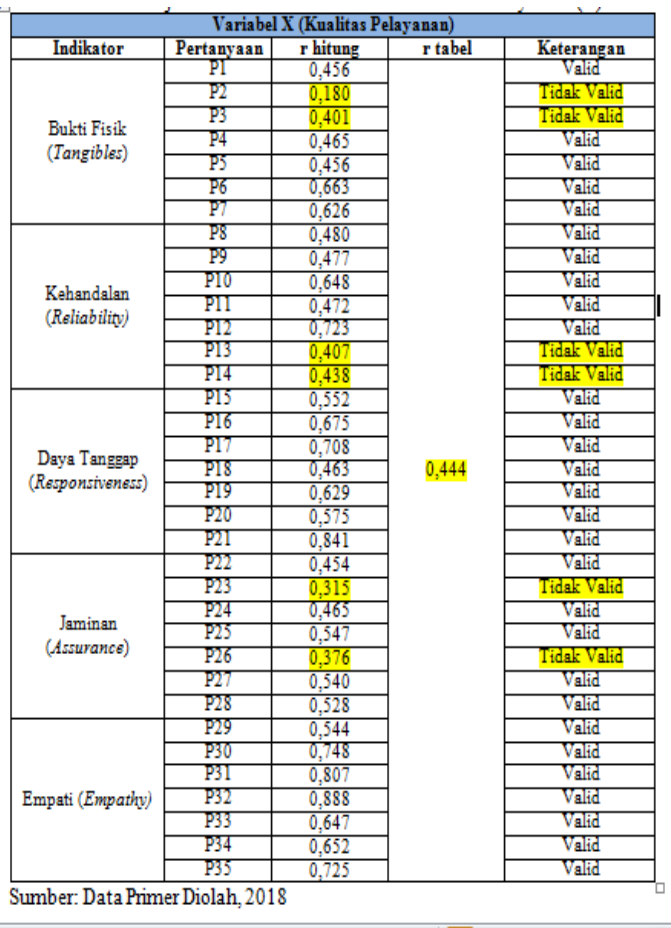


1. Uji Validitas

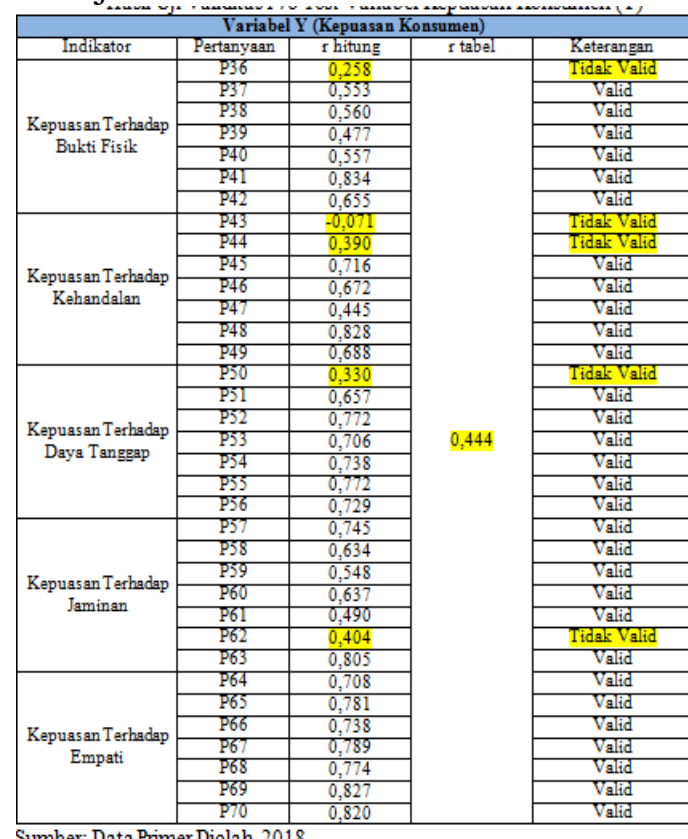

Berdasarkan tabel di atas dapat dilihat bahwa semua butir pertanyaan pada variabel kualitas pelayanan (X) dan semua butir pertanyaan pada variabel kepuasan konsumen (Y) memiliki nilai $r$ hitung yang lebih besar daripada nilai $r$ tabel. Dengan demikian dapat disimpulkan bahwa semua butir pertanyaan pada variabel kualitas pelayann (X) dan semua butir pertanyaan pada variabel kepuasan konsumen (Y) dinyatakan valid.

\section{Uji Reliabilitas}

Reliability Statistics Variabel Kualitas Pelayanan

\begin{tabular}{|r|r|}
\hline Cronbach's Alpha & N of Items \\
\hline, 931 & 35 \\
\hline
\end{tabular}

Pada tabel di atas dapat dilihat bahwa variabel kualitas pelayanan (X) memiliki koefisien reliabilitas yaitu sebesar 0,931. Hal ini menunjukkan bahwa variabel kualitas pelayanan (X) reliabel karena memiliki nilai koefisien reliabilitas di atas 0,6 .

Reliability Statistics Variabel Kepuasan Konsumen

\begin{tabular}{|r|r|}
\hline Cronbach's Alpha & N of Items \\
\hline, 949 & 35 \\
\hline
\end{tabular}

Pada tabel di atas menunjukkan bahwa variabel kepuasan konsumen (Y) memiliki koefisien reliabilitas yaitu sebesar 0,949. Hal ini menunjukkan bahwa variabel kepuasan konsumen $(\mathrm{Y})$ reliabel karena memiliki nilai koefisien reliabilitas di atas 0,6 .

b. Uji asumsi klasik

1. Uji Normalitas

Hasil uji normalitas dengan menggunakan uji kolmogorov-smirnov ini, yaitu:

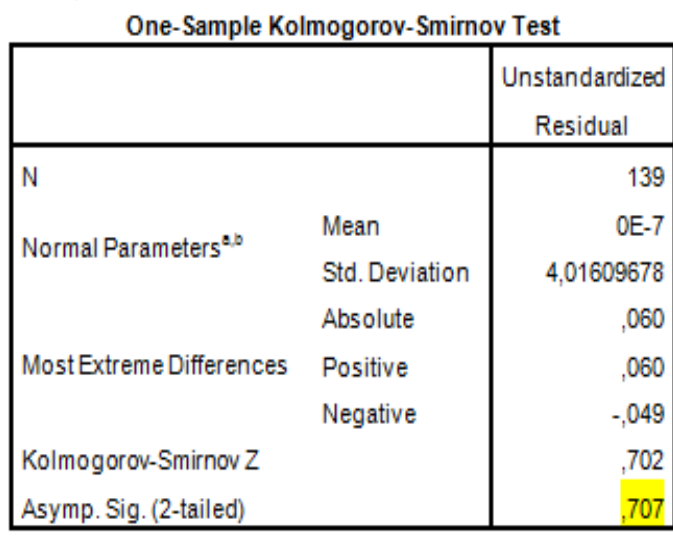

Berdasarkan tabel di atas dapat diketahui bahwa probabilitas (sig) yang diperoleh yaitu 0,707. Nilai probabilitas (sig) tersebut lebih besar dari taraf signifikansi penelitian yaitu $5 \%(0,05)$. Dengan demikian, dapat disimpulkan bahwa berdasarkan uji normalitas kolmogorov-smirnov data berdistribusi normal.

Grafik normalitas histogram dan grafik p-p plot pada penelitian ini, yaitu:

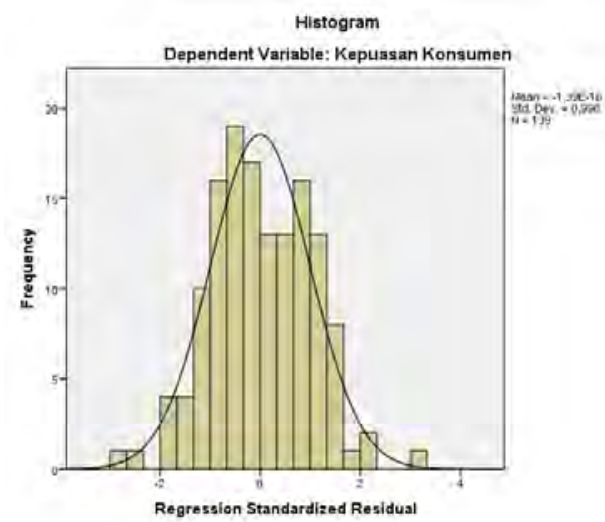




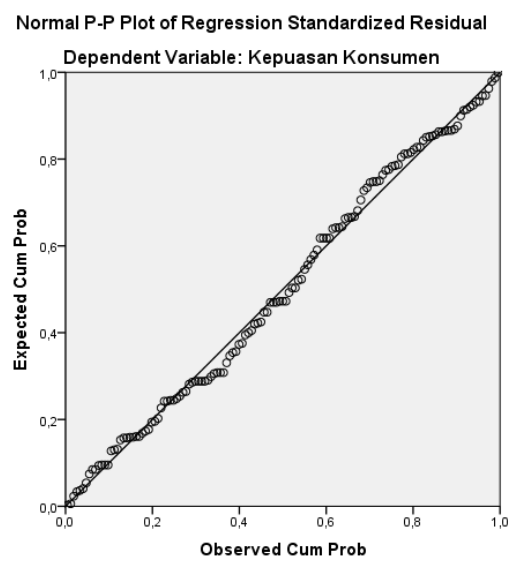

Berdasarkan hasil uji normalitas grafik histogram dan $p$-p plot di atas diperoleh data menyebar di sekitar garis diagonal dan mengikuti arah garis diagonalnya. Dengan demikian, kedua gambar grafik ini menunjukan bahwa model regresi pada penelitian ini memenuhi asumsi normalitas.

2. Uji Linieritas

Hasil uji linearitas pada penelitian ini, yaitu:

\begin{tabular}{|c|c|c|c|c|c|c|c|}
\hline & & & $\begin{array}{l}\text { Sum of } \\
\text { Squares }\end{array}$ & df & $\begin{array}{c}\text { Mean } \\
\text { Square }\end{array}$ & $\mathrm{F}$ & Sig. \\
\hline \multirow{6}{*}{$\begin{array}{l}\text { Kepuasan } \\
\text { Konsumen * } \\
\text { Kualitas } \\
\text { Pelayanan }\end{array}$} & \multirow{4}{*}{$\begin{array}{l}\text { Between } \\
\text { Groups }\end{array}$} & (Combined) & 4150,938 & 30 & 138,365 & 8,291 & , 000 \\
\hline & & Linearity & 3727,388 & 1 & 3727,388 & 223,363 & ,000 \\
\hline & & $\begin{array}{l}\text { Deviation } \\
\text { from }\end{array}$ & 423.551 & 29 & 14,605 & 875 & 650 \\
\hline & & Linearity & & & & & \\
\hline & \multicolumn{2}{|c|}{ Within Groups } & 1802,256 & 108 & 16,688 & & \\
\hline & \multicolumn{2}{|l|}{ Total } & 5953,194 & 138 & & & \\
\hline
\end{tabular}

Berdasarkan tabel 4.17 di atas dapat dilihat bahwa diperoleh probabilitas = $0,650>0,05$, maka dapat disimpulkan bahwa terdapat hubungan yang linier antara kualitas pelayanan terhadap kepuasan konsumen. Dari data tersebut dapat dipastikan kedua variabel tersebut memiliki hubungan linear yang signifikan, hal tersebut berarti bahwa perubahan yang terjadi pada variabel bebas akan cenderung diikuti oleh perubahan variabel terikat dengan dengan membentuk garis linear.

c. Uji hipotesis

1. Analisis Regresi Linier Sederhana Hasil analisis regresi linier sederhana pada penelitian ini, yaitu:

\begin{tabular}{|c|c|c|c|c|c|}
\hline \multirow[t]{2}{*}{ Model } & \multicolumn{2}{|c|}{$\begin{array}{l}\text { Unstandardized } \\
\text { Coefficients }\end{array}$} & $\begin{array}{c}\text { Standardized } \\
\text { Coefficients }\end{array}$ & $\mathrm{t}$ & Sig. \\
\hline & B & Std. Error & Beta & & \\
\hline $\begin{array}{ll} & \text { (Constant) } \\
1 & \text { Kualitas }\end{array}$ & $\begin{array}{r}15,677 \\
, 743 \\
\end{array}$ & $\begin{array}{r}2,935 \\
, 049\end{array}$ & ,791 & $\begin{array}{r}5,341 \\
15,147\end{array}$ & ,000 \\
\hline
\end{tabular}

Berdasarkan tabel di atas maka persamaan regresi yang diperoleh pada penelitian ini, yaitu:

$$
\mathrm{Y}=15,677+0,743 \mathrm{X}
$$

Penjelasan persamaan regresi di atas yaitu konstanta yang diperoleh pada penelitian ini sebesar 15,677, artinya jika kualitas pelayanan (X) nilainya 0 , maka kepuasan konsumen (Y) nilainya adalah 15,677. Nilai koefisien arah regresi pada penelitian ini yaitu positif 0,743 , artinya jika ada penambahan satu nilai atau angka pada kualitas pelayanan (X) maka akan ada kenaikan pada variabel kepuasan konsumen (Y) sebesar 0,743

2. Analisis Korelasi Sederhana Hasil uji korelasi antara variabel kualitas pelayanan dengan kepuasan konsumen, yaitu:

\begin{tabular}{|ll|r|r|}
\multicolumn{1}{|c|}{ Correlations } \\
\hline & \multicolumn{1}{c|}{$\begin{array}{c}\text { Kualitas } \\
\text { Pelayanan }\end{array}$} & $\begin{array}{c}\text { Kepuasan } \\
\text { Konsumen }\end{array}$ \\
\hline \multirow{4}{*}{ Kualitas Pelayanan } & Pearson Correlation & 1 &, $791^{-1}$ \\
& Sig. (2-tailed) & 139 &, 000 \\
& $\mathrm{~N}$ &, $791^{-}$ & 139 \\
& Pearson Correlation &, 000 & 1 \\
Kepuasan Konsumen & Sig. (2-tailed) & 139 & 139 \\
& $\mathrm{~N}$ &
\end{tabular}

Berdasarkan tabel di atas dapat diperoleh koefisien korelasi Pearson antara variabel kualitas pelayanan (X) dan kepuasan konsumen (Y) sebesar 0,791. Koefisien korelasi Pearson tersebut lebih besar dari nol atau 0,791 >0 artinya telah terjadi hubungan linear yang positif. Koefisien korelasi Pearson tersebut masuk dalam kelas interval kuat karena termasuk dalam rentang 0,60 - 0,799 yaitu 0,791 yang artinya terjadi hubungan yang kuat antara kualitas pelayanan (X) terhadap kepuasan konsumen(Y).

3. Koefisien Determinasi

Hasil koefisien determinasi pada penelitian ini, yaitu: 


\begin{tabular}{|l|c|r|r|c|}
\hline Model & $R$ & R Square & $\begin{array}{c}\text { Adjusted R } \\
\text { Square }\end{array}$ & $\begin{array}{c}\text { Std. Error of the } \\
\text { Estimate }\end{array}$ \\
\hline 1 &, $791^{\circ}$ &, 626 &, 623 & 4,031 \\
\hline
\end{tabular}

Berdasarkaan hasil perhitungan regresi menunjukkan bahwa nila $r$ square adalah sebesar 0,626. Hal tersebut menjelaskan bahwa sebesar $62,6 \%$ kepuasan konsumen pengguna Transjakarta dipengaruhi oleh variabel independen penelitian ini, yaitu kualitas pelayanan. Sedangkan 37,4\% sisanya dipengaruhi oleh faktor lain yang tidak diteliti pada penelitian ini.

4. Uji Signifikansi (Uji T)

Hasil uji signifikansi pada penelitian ini, yaitu:

\begin{tabular}{|c|c|c|c|c|c|}
\hline & & Coefficient & & & \\
\hline \multirow[t]{2}{*}{ Model } & \multicolumn{2}{|c|}{ Unstandardized Coefficients } & \multirow{2}{*}{$\begin{array}{c}\text { Standardized } \\
\text { Coefficients }\end{array}$} & \multirow[t]{2}{*}{$t$} & \multirow[t]{2}{*}{ Sig. } \\
\hline & B & Std. Error & & & \\
\hline \multirow{2}{*}{$1 \begin{array}{l}\text { (Constant) } \\
\text { Kualitas Pelayanan }\end{array}$} & 15,677 & 2,935 & \multirow[b]{2}{*}{, 791} & 5,341 &, 000 \\
\hline &, 743 &, 049 & & 15,147 & .000 \\
\hline
\end{tabular}

Berdasarkan tabel di atas diperoleh nilai t hitung sebesar 15,147. Nilai tersebut lebih besar dibandingkan dengan t tabel yaitu 1,977. Kemudian dapat dilihat nilai signifikansi $0,000<0,05$, artinya bahwa ada pengaruh yang nyata (signifikan) variabel X (kualitas pelayanan) terhadap variabel Y (kepuasan konsumen). Dengan demikian, dapat disimpulkan bahwa variabel kualitas pelayanan (X) berpengaruh signifikan terhadap variabel kepuasan konsumen (Y).

\section{KESIMPULAN DAN SARAN Kesimpulan}

Berdasarkan hasil analisis data dan pembahasan yang telah penulis uraikan sebelumnya, penulis dapat mengambil kesimpulan sebagai berikut:

a. Hasil analisis pada penelitian ini menunjukkan bahwa penelitian ini memenuhi syarat distribusi normal, dimana $0,707>0,05$. Selain itu terdapat hasil yang linear atau searah antar variabel karena 0,650 > 0,05. Dan hasil penelitian diketahui bahwa arah penelitian ini positif yaitu $\mathrm{Y}=$ $15,677+0,743 X$. Selain itu diketahui bahwa terdapat hubungan atau korelasi yang kuat antar variabel yaitu sebesar 0,791 .

b. Nilai pengaruh yang dihasilkan variabel kualitas pelayanan memiliki kontribusi yang cukup besar terhadap kepuasan konsumen pengguna transportasi umum Transjakarta yaitu sebesar 62,6\%. Sedangkan sisanya sebesar 37,4\% dipengaruhi oleh faktor lain diluar dari penelitian ini. Hasil analisis pada penelitian juga diperoleh bahwa nilai t hitung $(15,147)$ lebih besar dari nilai t tabel $(1,977)$. Hal ini menunjukkan bahwa kualitas pelayanan Transjakarta berpengaruh secara positif dan signifikan terhadap kepuasan konsumen yakni mahasiswa/i Administrasi Niaga Politeknik Negeri Jakarta.

c. Berdasarkan tanggapan responden terhadap kualitas pelayanan, diketahui indikator bukti fisik menciptakan hubungan yang paling kuat dengan nilai 601 dan indikator terendah adalah daya tanggap dengan nilai 525. Selain itu, tanggapan responden terhadap kepuasan konsumen diketahui indikator yang menciptakan hubungan paling kuat adalah kepuasan terhadap empati dengan nilai 598 dan indikator terendah adalah kepuasan terhadap bukti fisik dengan nilai 532.

\section{Saran}

Saran-saran yang dapat penulis berikan dalam penelitian ini adalah sebagai berikut:

a. Mempertahankan kebersihan di dalam bus Transjakarta seperti dengan cara disediakannya tempat sampah agar konsumen semakin puas dengan kebersihan Transjakarta. Selain itu, PT Transportasi Jakarta perlu mempertahankan kemampuan karyawan yang telah dapat memberikan pelayanan terbaik bagi perusahaan berupa hadiah (reward) seperti mengadakan family gathering, pemberian insentif dan sebagainya.

b. PT Transportasi Jakarta perlu meningkatkan perhatiannya kepada 
konsumen mengenai pemberian informasi yang diberikan perusahaan secara cepat (responsif) dan tepat seperti dengan ditempatkannya petugas disetiap halte untuk membantu konsumen mencari informasi yang dibutuhkan. Selain itu, PT Transportasi Jakarta perlu meningkatkan kualitas peralatan yang digunakan agar konsumen lebih puas ketika menggunakannya.

\section{DAFTAR PUSTAKA}

\section{Buku:}

Irawan, Handi. 2009. 10 Prinsip Kepuasan Pelanggan. Jakarta: PT Elex Media Komputindo Gramedia.

Kotler dan Keller. 2009. Manajemen Pemasaran. Edisi Ketiga Belas. Jilid 1 dan 2 Jakarta: Erlangga.

Lupiyoadi, Rambat. 2016. Manajemen Pemasaran Jasa. Jakarta: Salemba Empat.

Rahmayanty, Nina. 2013. Manajemen Pelayanan Prima. Yogyakarta: Graha Ilmu.

Siregar, Syofian. 2014. Statistik Parametrik Untuk Penelitian Kuantitatif. Jakarta: Bumi Aksara.

Sugiyono. 2010. Metode Penelitian Bisnis. Bandung: Alfabeta.

Sugiyono. 2011. Metode Penelitian Kuantitatif Kualitatif dan $R \& D$. Bandung: Alfabeta.

Tjiptono, Fandy. 2012. Service Management. Edisi Kedua. Yogyakarta: Andi

Umar, Husein. 2010. Riset Pemasaran \& Perilaku Konsumen. Jakarta: Gramedia Pustaka Utama.

Wijaya, Tony. 2011. Manajemen Kualitas Jasa Desain Servqual, QFD, dan Kano Disertai Contoh Aplikasi dalam Kasus Penelitian. Jakarta: Indeks.

Yamit, Zulian. 2013. Manajemen Kualitas Produk \& Jasa. Yogyakarta: Ekonisia.
Jurnal:

Destiana, A. H. (2015). Pengaruh Kualitas Pelayanan Terhadap Kepuasan Merchant Pada PT Bank Mandiri Persero Tbk Kantor Area Bekasi Jatiwaringin. Epigram, 9-19.

Endang dan, L. (2017). Pengaruh Fasilitas dan Kualitas Pelayanan Terhadap Kepuasan Penumpang Di Termial Rajekwesi Bojonegoro. Teknika, 911-915.

Fanny, F. (2016). Pengaruh Kualitas Pelayanan Pada Fasilitas dan Petugas Commuterline Ticket Vending Machine (C-VIM) Terhadap Kepuasan Konsumen PT KAI Commuter Jabodetabek Di Stasiun Pondik Cina. Epigram, 95-102.

Firmani, S. P. (2018). Analisis Pengaruh Kualitas Pelayanan Terhadap Kepuasan Konsumen Menggunakan Jasa Transportasi Umum PT. Cakra Transport Utama. Widyadari, 51-58.

Ridlo, Rochyan dkk. (2016). Pengaruh Kualitas Pelayanan Terhadap Kepuasan Konsumen (Studi Kasus pada Konsumen PT. Graha Service Indonesia Cabang Semarang). Journal Of Management, Volume 2 No. 2 Maret 2016

Wardani, K. F. (2014). Pengaruh Kualitas Pelayanan dan Harga Terhadap Kepuasan Pelanggan Bengkel Motor Pak Darus Di Kabupaten Purworejo. Oikonomia, 365-372.

\section{Website:}

http://www.republika.co.id/berita/nasional /jabodetabeknasional/18/03/21/p5y6 af330-transjakarta-jumlahpenumpang-meningkat-tiap-tahun Diakses pada 3 April 2018.

hhttp://transjakarta.co.id/tentangtransjakart a/struktur-organisasi/ Diakses pada 29 Juni2018 
